\title{
Eurasian Integration: Past, Present, and Future
}

\author{
Alexandra Okhrimenko, M. A. \\ Freie Universität Berlin, Berlin, Germany
}

\begin{abstract}
After the collapse of the Soviet Union, the post-Soviet area moved from the periphery of the world economy into a new centre of political and economic influence. Today, the concept of pragmatic (economic) Eurasianism by N. Nazarbayev plays a paramount role in the development of integration processes in Eurasia. One of the newest initiatives of Eurasian integration is the Eurasian Economic Union (EAEU), which functions today in a five-side format, comprising Russia, Belarus, Kazakhstan, Kyrgyzstan, and Armenia. However, conflict of interests, differential economic development among member states, and institutional problems often complicate the various processes of integration. On the other hand, with measures like harmonizing of national legislations, improved communication between countries at all levels, unification of trade policies, and enhanced control over domestic market in place, the EAEU countries also represent the newest competitive players in the world arena.
\end{abstract}

Keywords: regional economic integration, Eurasianism, Eurasian Economic Union, institutionalization, Post-Soviet area

\section{Introduction}

The collapse of the Soviet Union (USSR) significantly influenced the situation in Eurasia, which has since then moved from periphery of the world economy into a new center of political and economic influence. The newly formed post-Soviet states refused to implement a planned economy; instead, they opted for a gradual rapprochement and restoration of the economic ties that were lost during the disintegration. Internationalization has compelled national economies to be dependent on external economic and political factors, thereby necessitating greater degrees of international cooperation. These inevitable processes also found their place in Eurasia.

Various organizations preceded the establishment of the Eurasian Economic Union (EAEU), as part of a long, difficult process characterized by ambiguous expert estimates. The Central Asian Union, the Transport Union, the five-state Customs Union and Single Economic Space, the Union State between Russia and Belarus, the Eurasian Economic Community, and the Customs Union of Russia, Belarus and Kazakhstan — each of these organizations helped to set the legal, institutional, and ideological foundation for the subsequent establishment of the Eurasian Economic Union in 2015.

The EAEU is a new international organization for regional economic integration. The treaty on Establishment of the EAEU was based on the agreement of the Customs Union and the Common Economic Space among Russia, Belarus, and Kazakhstan. According to the treaty, this economic union was created for consolidation, modernization as well as for increasing the sense of competition among the national economies of member states in the global market.

Alexandra Okhrimenko, M.A., Ph.D. candidate, Caspian Region Environmental and Energy Studies, Freie Universität Berlin. 


\section{From the Ideas of Eurasianists to the Idea of Nursultan Nazarbayev}

The ideological vacuum that resulted from the failure of communistic idea was eventually filled with several ideas, and Eurasianism was one such concept. Eurasian ideas and the concept of Eurasianism first appeared around the 1920s in the milieu of Russian emigrants in Europe. Its purpose was to explain the existence as well as evaluate the prospects of the newly formed Union of Soviet Socialist Republics. The key representatives of Eurasianism, such as Petr Savickij and Nikolai Trubetzkoy, attempted to rethink the history of Eurasia and looked for new and special ways for the development of the Soviet Union. It should be noted that in the 1920s, Eurasianism developed not only as a historical and philosophical concept, but also as a peculiar political doctrine. This doctrine outlined a clear opposition between "West" and "East" and reckoned Russia to be the connecting bridge between these two civilizations.

In the 1970s, the concept of Eurasianism revived with the publication of Lev Gumilyov's "Ethnogenesis and the Biosphere of Earth". Though Gumilyov didn't use a political approach, his ideas bear a general resemblance to western geopolitical concepts. In due course, the Eurasian idea underwent essential changes, with some versions even containing openly radical lines.

The idea of pragmatic (economic) Eurasianism as put forward by the Kazakh president, Nursultan Nazarbayev, however, plays an important role in the development of Eurasian integration processes even today. While the conclusions drawn by the first Eurasianists may have lost their relevance in present times, the concept of Eurasianism still forms most of the general fundamental framework and can be considered from the new sides.

Nazarbayev's approach to Eurasianism assumes the re-establishment of economic, political and cultural ties between the states of the former USSR, based on new principles and conditions that correspond, first of all, to modern economic realities. He further emphasizes that the integration of the sovereign post-Soviet states must be on equal terms. Primarily, the integration must be directed towards the realization of the national interests of each partner of the Eurasian integration, as well as the renunciation of political pressure and armed conflicts. According to Nazarbayev, the integration has to facilitate the consolidation of stability and safety, as well as social and economic modernization in the post-Soviet area (Nazarbayev, 1994). This approach to Eurasianism can be seen as the ideological base for the modern integration process in Eurasia. Furthermore, it can also play a key role in the development of a new Eurasian political strategy.

In recent times, the concept of economic Eurasianism has been actively developed not only by the Kazakh president, but also by the scientific community. Authors, such as Vinokurov and Libman (2012a), Dutkiewicz and Sakwa (2015), Fedorenko (2015), et al. have devised scientific approaches, determining the current state and further direction of the Eurasian integration. As per pragmatic (economic) Eurasianism, integration could become the key force of economic development in the Eurasian continent, especially with respect to trade in energy resources, integration in the transport sphere, integration of capital and labor, tourism and fight against drugs, and epidemiological threats (Vinokurov \& Libman, 2012b).

\section{Institutionalization of Integration in the Post-Soviet Area}

On 21 December, 1991, the USSR was finally dissolved in Alma-Ata, followed by the signing of the declaration among Azerbaijan, Armenia, Belarus, Georgia, Kazakhstan, Kyrgyzstan, Moldova, Russia, Tajikistan, Turkmenistan, Uzbekistan, and Ukraine. This declaration contained the main purposes and reasons 
behind establishing the Commonwealth of Independent States (CIS). The summit was an important point in the finishing of the process of transition from the USSR to the CIS. After the collapse of the USSR, the newly formed states underwent a long period of economic crisis. They essentially needed the restoration of the lost intergovernmental connections, because many production processes in the USSR were scattered over several Soviet republics.

A crucial factor at that time was the high level of mutual distrust: the establishment of Russia as the successor of the USSR caused apprehension among other CIS members. In the 1990s, many local conflicts broke out in the post-Soviet area, such as the ones in South Ossetia, Transnistria, or Tajikistan. However, several attempts were also actively made to establish peace. In this order, in the framework of security the Council of CIS Defence Ministers was formed to coordinate the military policy of the CIS member states. Subsequently, the Collective Security Treaty was signed among Armenia, Russia, Kazakhstan, Kyrgyzstan, Belarus, Georgia, Tajikistan, and Uzbekistan, which was the basis of the Collective Security Treaty Organization created in 2000.

The role of Russia as a political and economic player in the post-Soviet area is huge, although the majority of integration initiatives in the region belong to Kazakhstan. Since the 1990s, Nazarbayev (2011) put forward various integration initiatives which have since appeared in different publications. The main focus of the integration initiatives was directed at Central Asia: Kyrgyzstan, Tajikistan, Uzbekistan, and Turkmenistan. Thereby, in 1993, the agreement on the establishment of the Central Asian Union was signed by Kazakhstan, Uzbekistan, Kyrgyzstan, and years later by Tajikistan. In two years, a new initiative - the establishment of the Customs Union - came about in the post-Soviet area. Russia, Belarus, Kazakhstan, and later Kyrgyzstan, actively participated towards building a new integration association. Another project of this time was the establishment of the Transport Union among Russia, Belarus, Kyrgyzstan, and Kazakhstan.

In 1999, the economic cooperation extended further due to the agreement on the five-state Customs Union and a Single Economic Space. At the same time, Russia and Belarus signed the agreement on the Union State of Russia and Belarus. However, the twin spheres of integration and cooperation were unable to develop effectively across such a large number of organizations. Therefore, the decision to establish the Eurasian Economic Community was made in 2000. Apart from the permanent members-Russia, Belarus, Kazakhstan, Kyrgyzstan, and Tajikistan - the observer status in the Eurasian Economic Community was granted to Ukraine, Moldavia, and Armenia. In 2007, Russia, Kazakhstan and Belarus signed the agreement on a Customs Union, which laid the legal, institutional and ideological foundation for the subsequent establishment of the Eurasian Economic Union.

The agreement on establishment of the Eurasian Economic Union was signed in May 2014, and it came into force from January 2016. In present times, the EAEU functions in a five-side format: Russia, Belarus, Kazakhstan, Kyrgyzstan, and Armenia. The purpose of the EAEU is to create conditions for stable development of member state economies, increase the living standard of their populations, and form a single market for goods, services, capital, and labour within the Union, along with comprehensive modernization, cooperation, and promotion of competitiveness amongst national economies. To realize these purposes, the EAEU member states implement a coordinated macroeconomic policy in the currency, transport, agrarian, and industrial sphere.

The EAEU's highest authority is the Supreme Eurasian Economic Council represented by the heads of the member states; the Eurasian Intergovernmental Council is formed by the heads of the member state 
governments, and the Eurasian Economic Commission consists of Board and Council. The judicial authority of the Union is the Court of the EAEU (Treaty on the Eurasian Economic Union, 2015).

\section{Factors Complicating Eurasian Economic Integration}

Economic integration in the post-Soviet area appears to be a very complex process at first glance, but it develops logically and consistently: a free trade area - a customs union-a single market for goods, services, capital, and labor - a payment and currency union. At the same time, institutional problems such as conflict of interests and differential levels of economic development among member states complicate the development of the integration processes. Moreover, external factors, such as western sanctions against Russia, leave traces on the course and depth of the integration in the region.

The Eurasian integration process appears complicated, firstly due to differential levels of economic development among member states, which results in an asymmetric integration. In this context, asymmetric refers to integration between partners at differential levels of development, which is in contradiction with the European principle of synchronous integration that assumes a synchronous transition from one integration level to another. In such cases, the difference in levels of social and economic development of the member states is thereby equalized. This was not the case with the member states of the EAEU during the establishment of the Eurasian Economic Union.

Without a doubt, Russia was and remains the absolute economic leader in the region: from January-December 2015, the GDP of the EAEU was worth 1,580,102.6 million US dollars, and Russia's share amounted to 1,325,627.2 million US dollars, exceeding 83.8\% the EAEU GDP (Eurasian Economic Commission, 2016).

Presently, however, with the current economic crisis and falling oil prices, Russia is the main destabilizing factor for the EAEU, since the national economies of member states highly depend on the economy of Russia. Besides, the short-term integration effect which helped strengthen mutual trade in the past is levelling, and consequently intensifying the competition in the EAEU domestic market. The accession of Armenia and Kyrgyzstan under such difficult economic conditions made the EAEU even more economically diverse, as the backwardness of their domestic economies reduced the general economic capacity of the Union. Moreover, Armenia has no common border with the EAEU countries, which significantly reduces the level of economic interaction between the member states and Armenia.

Other factor complicating the Eurasian integration includes the various interpretations of its purposes and problems among the EAEU member states. For instance, Russia interprets the Eurasian integration not as a reinforcement of economic interaction, but rather as an expensive way to attain political support among former Soviet republics, as well as an expansion of its influence zones. Russia puts its own political interests above the interests of EAEU as can be confirmed by its implementation of retaliatory sanctions on import of agricultural products from Europe. The sanctions, unilaterally declared by Russia against Europe, have a direct impact on the intensification of contradictions between the EAEU member states, thereby breaking the principles of the economic union.

On the other hand, Belarus is primarily interested in economic partnership and seeks to avoid political destabilization in every possible way. The preservation of domestic and foreign political status quo is the main factor supporting the national economy of Belarus. In the context of the Russian-Ukrainian relations crisis, Belarus looks for balance and tries to prevent the political instability that can arise due to increased Russian 
military presence in the territory of Belarus. Nevertheless, Belarus is directly interested in strengthening its interaction with Russia. For example, in March 2015, Minsk and Moscow signed an agreement on issuing a state financial credit of 110 million US dollars for Belarus (Siwickij \& Carik, 2016).

Kazakhstan, like Belarus, seeks only economic integration. Although, Kazakhstan contributes only $20 \%$ in the total foreign trade turnover of EAEU countries (Ministry of National Economy of the Republic of Kazakhstan; Committee on Statistics; Foreign Trade 2015, 2015), Astana nevertheless considers EAEU as a springboard for the intensification of trade interactions with countries in Europe and Asia. It insists on political independence of the EAEU member states and seeks to avoid an open political support of any member state. Therefore, in connection with the renewed conflict in Nagorno-Karabakh, Kazakhstan insisted on transferring the EAEU summit from Yerevan to Moscow on 8 April 2016, as a meeting of the heads of the EAEU member governments in Yerevan could indicate indirect support for Armenia in the Armenian-Azerbaijani conflict.

On the other hand, Armenia considers its accession to the EAEU as recognition of its claims in the frozen Nagorno-Karabakh conflict, and counts on the support of Russia, which stations the military base in Armenia. Moreover, under the Turkish and Azerbaijani economic blockade, Armenia is compelled to strengthen economic relations with its main economic partner-Russia. The general share of Russia in the Armenian economy is $82 \%$ (Statistical yearbook of Armenia, 2015). In this regard, economic integration with Russia is essential for Armenia to find a way out of this geographical and economic impasse.

Meanwhile, given Kyrgyzstan's condition of economic decline, its accession to the EAEU can be viewed as the only practical way of overcoming the crisis, even if that means giving up on political independence to a certain extent.

Another factor complicating the integration processes is the problem of Supranationalism. In spite of the fact that the governing bodies of the Eurasian Economic Union are supranational by law (Treaty on the Eurasian Economic Union, 2015); in reality, they are not. A distinctive feature of supranational bodies is the obligation of their decisions upon all member states. In the EAEU, the decisions made by the Eurasian Economic Commission, which obligatory for implementation under the treaty on the EAEU, are sometimes partially observed by the member states, and at times, not at all. Russia, seeking to minimize the losses from an economic crisis and the western sanctions, hereby began a state programme of import substitution industrialization (ISI) without the participation of other EAEU members. Kazakhstan, on its end, joined the World Trade Organization (WTO); again, without coordinating with other EAEU members, Armenia entered the frozen conflict in Nagorno-Karabakh, and despite the economic nature of the Eurasian integration, now demands political support from the EAEU member states (TASS, 2016). Belarus unilaterally prolonged the period for not applying to the EAEU's technical regulations for its domestic business owners (Siwickij \& Carik, 2016). All this indicates the advancing institutionalization in the region, where member states don't to follow their national interests rather than the interests of the integration community. Moreover, they are not ready to give up a part of their sovereignty, which is necessary for the normal functioning of supranational bodies.

\section{Prospects of the EAEU}

The Eurasian integration opens up big prospects for its member states. The active developing process of harmonization of national legislations leads to improvement in communication between the countries at all levels of interaction. The development of a coordinated trade policy and the improvement of control measures 
over domestic market promote a positive perception of the EAEU countries as the new competitive players in the world arena.

An important prospect for the EAEU as the part of global integration process is the expansion from post-Soviet Eurasian integration to continental Eurasian integration (Vinokurov \& Libman, 2012). While the post-Soviet Eurasian integration takes into account only the countries of the ex-USSR, the continental Eurasian integration means further expansion along the axis of the European Union (EU) - the Eurasian Economic Union (EAEU) - the Asia-Pacific Economic Cooperation (APEC). Thereby, this covers the whole continent of Eurasia. The prospects of this transformation are defined by the economic relations already established between the member states of these integration associations. For instance, in 2015, the main buyer of goods exported by the EAEU member states is the European Union (53.2\% of cumulative export). Among the countries of the EU, the goods are delivered mostly to the Netherlands (12.6\%), Italy (8.2\%), Germany (7.2\%), the United Kingdom (3\%), and Poland (3\%). About $23.6 \%$ of the exported goods are sold to the APEC countries: $9.4 \%$ to China, $4.1 \%$ to Japan, and $3.8 \%$ to South Korea. The export deliveries to Turkey made $5.6 \%$ of the total amount of the EAEU export. The import purchases of the EAEU are concentrated in the countries of the APEC and the European Union $(40.5 \%$ and $40.9 \%$ of the cumulative import of goods, respectively). Among the APEC countries, significant deliveries of goods are from China (21.3\%), the United States (6.6\%), Japan (3.7\%), and South Korea (2.6\%). Among the EU countries, the greatest volumes of imports are shared by Germany (11.7\%), Italy (5\%), and France (3.4\%). About $2.7 \%$ of cumulative imports to the EAEU are from Turkey (Eurasian Economic Commission: The EAEU statistics; Statistics on foreign and mutual trade in goods in 2015, 2016).

\section{Conclusions}

The transformation of the post-Soviet region to a peculiar bridge between Europe and Asia along the axis of EU-EAEU - APEC will give it new global significance as a key figure in continental economy. For such a transformation to materialize, it is necessary to facilitate dialogue between the countries and eliminate the existing antagonism between Europe and Russia. In this context, Nursultan Nazarbayev's (1994) concept of pragmatic Eurasianism can play a crucial role in the harmonization process and actively promote and improve interstate relations between the integration partners. In view of the Ukrainian-Russian trust and relations crisis and the western sanctions against Russia, Kazakhstan can be seen as a particularly favorable and reliable integration partner, both for Europe and for Asia.

\section{References}

Dutkiewicz, P., \& Sakwa, R. (2015). Eurasian integration: The view from within. New York: Routledge.

Eurasian Economic Commission. (2016, March 6). Analytical Review. Retrieved April 22, 2016, from http://eec.eaeunion.org/ru/act/integr_i_makroec/dep_stat/econstat/Documents/Indicators201601.pdf

Eurasian Economic Commission: The EAEU statistics; Statistics on foreignand mutual trade in goods in 2015. (2016, February

26). $\quad$ Retrieved April $\quad 27, \quad$ from

http://eec.eaeunion.org/ru/act/integr_i_makroec/dep_stat/tradestat/analytics/Documents/Analytics_E_201512.pdf

Fedorenko, V. (2015). Eurasian integration: Effects on Central Asia. Rethink Paper (23).

Ministry of National Economy of the Republic of Kazakhstan; Committee on Statistics; Foreign Trade 2015. (2015). Retrieved

April 26, 2016, from http://stat.gov.kz/faces/wcnav_externalId/homeNumbersCrossTrade2015?_afrLoop=33531411232732317\#\%40\%3F_afrLoo p\%3D33531411232732317\%26_adf.ctrl-state\%3Dg1pkko5f7_110

Nazarbayev, N. (1994, Juny 3). Project of the Eurasian Union. 
Nazarbayev, N. (2011, October 26). Eurasian Union: From the idea to the history of future. Izvestia-Kazakhstan.

Siwickij, A., \& Carik, Y. (2016). Belarus in the EAEU: One year later (in Russian). Retrieved April 26, 2016, from http://csfps.by/files/files/belarus_in_the_eaec.pdf

Statistical yearbook of Armenia 2015. (2015). External economic activity. Retrieved April 26, 2016, from http://www.armstat.am/file/doc/99493858.pdf

TASS. (2016, April 8). Armenia voices regret over transfer of Eurasian Economic Union summit from Yerevan. Retrieved April 27, 2016, from http://tass.ru/en/economy/868178

Treaty on the Eurasian Economic Union. (2015, January 1). Retrieved April 19, 2016, from https://docs.eaeunion.org/docs/en-us/0017353/itia_05062014_doc.pdf

Vinokurov, E., \& Libman, A. (2012a). Eurasian integration: Challenges of transcontinental regionalism. Basingtoke: Palgrave Macmillan.

Vinokurov, E., \& Libman, A. (2012b). Eurasian continental integration. Saint-Petersburg: EDB. 